\title{
Using the Soil and Water Assessment Tool (SWAT) to Assess Material Transfer in the Layawan Watershed, Mindanao, Philippines and Its Implications on Payment for Ecosystem Services
}

\author{
Leo Kris M. Palao ${ }^{1}$, Moises M. Dorado ${ }^{2}$, Kharmina Paola A. Anit ${ }^{1}$ \& Rodel D. Lasco ${ }^{1,2,3}$ \\ ${ }^{1}$ International Centre for Research in Agroforestry, Los Baños, Laguna, Philippines \\ ${ }^{2}$ University of the Philippines Los Baños, Laguna, Philippines \\ ${ }^{3}$ National Academy of Science and Technology (NAST), Philippines \\ Correspondence: Rodel D. Lasco, International Centre for Research in Agroforestry, Los Baños, Laguna 4031, \\ Philippines. Tel: 49-536-2701 ext 2675. E-mail: R.Lasco@CGIAR.org
}

Received: February 28, 2013 Accepted: April 30, 2013 Online Published: May 27, 2013

doi:10.5539/jsd.v6n6p73 URL: http://dx.doi.org/10.5539/jsd.v6n6p73

\begin{abstract}
Soil and water are the most important resources in the watershed. The alterations on the quantity and quality of these resources do not only have on-site impacts, but are experienced by off-site communities as well. To assess the material transfer and identify critical sub-basins in the Layawan Watershed, Mindanao, Philippines; the Soil and Water Assessment Tool (SWAT) Model was used. The model was also used to investigate changes in land use. Results show that a $4 \%$ reduction in sediment concentration and sediment yield in the critical sub-basins will be achieved if the community-based watershed management plan is implemented. On the other hand, there will be a $106 \%$ increase in sediment concentration and sediment yield if forests are cleared for utilization, primarily for agriculture, in the critical sub-basins. Modeling sediment yield and sediment concentration is important to help policy makers, environmental managers, and development agencies predict the impact of activities on soil and water quality, as well as guide them in the implementation of payments for ecosystem services (PES) schemes. The quantification of ecosystem services has been a major challenge surrounding the success of PES. In the Layawan Watershed, it is shown that land change use will not likely affect water quantity, it will, however, heavily impact water quality. Modeling provides an avenue to manage watersheds effectively and efficiently. SWAT running on open source GIS could help budget-constrained government units and development agencies to better predict the impact of programs and projects on watersheds.
\end{abstract}

Keywords: SWAT, modeling, soil erosion, sedimentation, watershed, Layawan Watershed, Payments for Ecosystem Services (PES), land use change

\section{Introduction}

Soil and water are critical resources in the watershed that should be managed properly for continued supply of ecosystem services, such as good water quality and quantity, to support a wide and diverse range of utilization such as irrigation, agricultural production, domestic and industrial uses, or combination thereof. However, many of the watersheds in developing countries are in a state of degradation as a result of overexploitation and mismanagement of land resources. Excessive soil erosion is one of the manifestations of land degradation. Many issues, such as sedimentation, ecological degradation, and pollution, are also associated with soil erosion, and may affect aquatic and coastal ecosystems as well (George \& Leon, 2007). Land mismanagement can often be attributed to the lack of understanding of the impact of human activities on soil and water resources since watershed stakeholders do not have a tool to investigate the impact of proposed activities.

Understanding the mechanism that drives the hydrologic processes is complex, and models are often used to simplify these processes into a more comprehendible manner. Modeling is a tool used to assess the current condition of the watershed, and to investigate the consequences of actions and interventions on soil and water resources. Through modeling, the consequences of various actions and interventions in a watershed can be quantified; hence it is a vital tool in watershed management. 
One conservation tool that can benefit from this is Payments for Ecosystem Services or PES. In a PES scheme, those who provide environmental services such as biodiversity conservation and watershed protection, among others, are being paid by those who benefit from those services. One particular challenge faced by this tool is the concept of additionality. The payments from the beneficiaries for the ecosystem services will only be sustained if there is a clear additionality provided (Wunder, 2005). This means a clear baseline scenario and quantification of the ecosystem services being provided. In cases where data available is limited and actual impacts of land use interventions are still to be realized in a few more years, simulation modeling can be very useful (Lasco et al., 2008). So far, few studies in the Philippines have been conducted to assess current hydrologic processes, and to quantify the changes in soil and water resources in relation to land use change.

In light of these, the study was conducted with the following objectives: quantify sediment yield and sediment concentration in Layawan Watershed using the Soil and Water Assessment Tool (SWAT) Model; and (2) showcase how modeling, especially the use of models built in open source GIS, can aid in the implementation of PES.

Soil erosion and siltation is an enduring and serious problem experienced by many watersheds in the Philippines, however, many still ignore the compounding problems of soil erosion and siltation until it reaches an alarming state. By then, the impacts have become irreversible. It adversely affects ecosystem services, such as availability of nutrients (depletion or over-enrichment), and alters hydrologic regimes that may have detrimental impacts to downstream communities and ecosystems. Siltation is closely linked with soil erosion (i.e., surface erosion, gully erosion, soil mass movement, or stream channel erosion), such that excessive sediment levels in streamflow is a manifestation of high soil erosion rate in a watershed (Brooks et al., 2003). It is dependent on several factors, such as the proximity of the erosional feature to the channel, characteristics of the sediment particles, and the efficiency by which sediment particles are transferred from one part of the landscape to another (Brooks et al., 2003). During the process of sedimentation, different chemicals may also enter the water body and this affects water quality vis-à-vis water utilization. Sediment concentration and sediment yield affect the productivity of terrestrial and aquatic ecosystems since soil has high affinity to chemicals (i.e., toxic metals and nutrients) and can serve as repositories and sinks. Due to this process, soil can carry pollutants to the stream and can impair ecosystem functions. However, it might not immediately manifest because of immobilization and storage in the soil particles (Burden et al., 2002). This implies that the more soil is transported into the stream, the greater the chance that the water will be polluted and can lead to irreversible damage.

The hydrologic regime, such as stream flow, erosion, and sediment transport in a watershed is mainly the product of existing climate, land use, soil, and topography. The extent, arrangement, and how land use is practiced determines the timing, amount, and occurrence of hydrologic processes and consequently affects the condition of soil and water resources. Among these factors, land use is the most likely to change, since it is sensitive to economic, policy, and social forces (Palao, 2011). Land use plays a major role in alleviating soil erosion, and the only variable that can be changed and practically managed with human intervention. Land use change is an important consideration in watershed management, hence any activities that might change the surface cover should be carefully examined in relation to soil loss and sediment transport.

\subsection{Brief Model Description}

Many applications of the SWAT Model are being used by developed countries due to the expensive cost of a commercial GIS license. To make the model available to a wider range of users, the United Nations University developed an open source interface to SWAT called MapWindowSWAT or MWSWAT. This SWAT Model was developed by the USDA Agricultural Research Service (USDA ARS) and Texas A\&M AgriLife Research to predict the impact of various land uses and management practices on water, sediments, and agricultural chemical yields in large complex watersheds over long periods of time (Neitsch, 2005). The SWAT Model is a continuous time model, meaning it cannot be used to predict single-event flood routing. No matter what type of problem is studied with SWAT, water balance is still the main driving force behind everything that happens in the watershed.

Simulation of the hydrology of a watershed can be separated into two major divisions, the first division being the land phase of the hydrologic cycle. The land phase of the hydrologic cycle controls the amount of water, sediment, nutrient and pesticide loadings to the main channel in each sub-basin. The second division is the water or routing phase of the hydrologic cycle which can be defined as the movement of water, and sediments, among others, through the channel network of the watershed to the outlet. Sediment concentration in the river network modeled by SWAT involves deposition, degradation, and re-suspension as a function of peak channel velocity 
(Neitsch, 2005). The SWAT version being used in this study runs on an open source GIS platform - MWSWAT. This initiative seeks to promote the use of the SWAT Model in developing countries.

The SWAT Model involves three basic steps: the first step delineates the watershed boundary, sub-watersheds, and river network. After this process, SWAT will give a report on the watershed topography. The second step is the creation of hydrologic response units (HRUs). The HRUs are lumped areas within the sub-basins that have similar land cover, soil, and management combinations. The last step is the model set-up and run. In this step, the user will have to select meteorological data, indicate simulation period, write SWAT files in the right format, and run the model (George \& Leon, 2007).

Visualization is an additional feature of MWSWAT. The visualization button will become live after the model has been run. This feature allows the user to create shapefiles of various output variables of SWAT.

\subsection{SWAT Model Applications}

The SWAT Model is one of the most widely used and scientifically accepted tool for assessing water quality, sediment transport and streamflow in a watershed; as evidenced by worldwide conferences and publications of SWAT related reports and articles. The use of the model is primary driven by the demand of various environmental agencies for direct and exploratory assessments of the impact of anthropogenic activities, climate change, and other wide range of land management issues on water and soil resources (Gassman et al., 2007). Since many watersheds globally are already experiencing degradation and calls for sound management of resources, SWAT has been increasingly used even outside of the United States of America. According to Arnold et al. (2009), the SWAT model has also been used in countries such as China, Iran, Japan, Korea, Philippines, as well as countries in Europe and in Africa.

In the Upper Nile Basin in Africa, SWAT has been used for hydrology/water balance, erosion, water quality, and climate change assessments, calibration uncertainty, land use change studies, and SWAT development (van Griensven et al., 2012). Additionally, Gassman et al. (2007) showed that the global application of SWAT included calibration and/or sensitivity analysis, climate change impacts, GIS interface descriptions, hydrologic assessments, variation in configuration or data input effects, comparison with other models or techniques, interfaces with other models, and pollutant assessments.

In the Philippines, the SWAT Model has been used to investigate the impact of land use change, such as conversion of grasslands and forestland to agricultural lands, on runoff and sediment yield (Alibuyog et al., 2009). In their study of the Manupali Watershed, result showed that if $50 \%$ of the pasturelands and grasslands will be converted to cultivated lands there will be a drastic increase in sediment yield, and will consequently decrease the baseflow by $2.8 \%$ to $3.3 \%$. The paper of Ullrich (2009) indicated that SWAT is sensitive to crop rotations and, to some extent, management practices. In East Africa, SWAT was used to investigate the hydrologic impact of land use change over a 17-year period in the Njoro River. Results suggest that it will lead to a decrease in groundwater recharge due to an increase in surface runoff, and will have a negative impact on the lake ecosystem.

The SWAT Model has also been used to study crosscutting issues, for example climate change is integrated in hydrologic assessments and land use change studies. Climate change can be integrated in SWAT either by testing the effects of increased atmospheric $\mathrm{CO}_{2}$ concentration $\left(\mathrm{CO}_{2}\right.$ scenarios) on plant growth and changes in weather parameter inputs (climate scenarios). This type of application is critical in managing water resources and agricultural systems. In the study of Lirong and Jianyun (2012), they used the SWAT model to assess the changes in streamflow in the Beijing River Basin using 15 sets of climate change scenarios. Accordingly, the model showed good results. In the study of Ficklin et al. (2009), they used the Model to assess the hydrologic sensitivity of the San Joaquin Watershed to climate change. The study showed that the watershed is very sensitive to potential future climate scenarios. The results revealed that a $37.5 \%$ decrease in evapotranspiration (ET) will lead to an increase in water yield (36.5\%) and streamflow (23.5\%), and that increased temperature can cause temporal shifts in plant growth patterns which will affect ET and irrigation water demand. However, increase in precipitation by $\pm 10 \%$ and $20 \%$ generally changes the streamflow and water yield, and will have negligible effects on predicted ET and irrigation water use. In the study of Zhi et al. (2009), it was indicated that SWAT has been useful and yielded satisfactory results when used in assessing of effects of environmental changes including land use change and climate change in the Loess Plateau in China. Moreover, Moradkhani et al. (2010) used the SWAT Model and floodplain analysis to predict future floodplain and riparian ecotone based on various climate scenarios suggested by Global Circulation Models. 


\section{Materials and Methods}

\subsection{Background of the Study Area}

The Layawan Watershed has a total land area of 10706 hectares (based on GIS delineation using 90-meter DEM) and it is located in the Northwestern portion of Mindanao. It is within the Mt. Malindang Range National Park in Misamis Occidental, Philippines (Figure 1). The watershed lies within $8.28139 \mathrm{~N}$ and $8.52250 \mathrm{~N}$ latitude and $123.61778 \mathrm{~N}$ and $123.82028 \mathrm{~N}$ longitude. Dominant land use is forest $(29 \%)$ and coconut plantations with tree intercrops $(61 \%)$ - based on observation and land cover analysis of Landsat $5 \mathrm{TM}$. The watershed covers 33 barangays in six towns (GADM, 2011). It has a total stream length of 62 kilometers comprised of 11 first order streams and 2 second order streams. This gives a stream density of $0.006 \mathrm{~km} / \mathrm{ha}$. The shape of the watershed is elongated, and this reflects that the watershed has extensive areas of steep slopes.

The topography of the Layawan Watershed is considered to be steep in which almost half (45.26\%) of its slope is greater than $50 \%$ and soils are considered to be erodible. In the upland and midland portion of the watershed, soils belongs to three soil textural classes, these are Adtuyon clay loam, Guimbalaon clay loam, and Mountain soils, undifferentiated (Bureau of Soils, 1970). These soil textural classes are considered as Class M and $\mathrm{N}$ by the Bureau of Soils. Class M indicates steep, very severely to excessively eroded or shallow for cultivation which is suited for pasture or forest with careful management, while Class $\mathrm{N}$ indicates very steep, excessively eroded, shallow rough, or dry cultivation which is suited for pasture with very careful management and definite restrictions and is best suited for forest with very careful management (Bureau of Soils, 1970). The major land uses in the critical sub-basins is coconut, which comprises $54 \%$ to $94.65 \%$ of the sub-basins land area. Majority of the slope as classified as $\mathrm{E}(30-50 \%)$ and $\mathrm{F}(>50 \%)$ which comprises $52 \%$ to $77 \%$, respectively. According to the Bureau of Soils (ND), the nature of slope and dominant vegetation class can be considered as areas having moderate (E2) erosion. This was reflected in the model, where the critical sub-basins are located in areas where soils are considered to be erodible and has steeper slopes. The critical sub-basins comprised almost half of the total land area of the watershed.

Agriculture is the mainstay and the primary livelihood of the locals living within the watershed. In 2003, the community in the watershed has a total population of 26041 making up to 5311 households (DENR, 2003). In the headwaters (covered by the core zone), there are presence of communities which are also engaged in agricultural activities. Moreover, a group of indigenous people, the Subanens, have been granted their ancestral domain claim (Oroquieta Ancestral Domain Claim) with a total area of 6610 hectares, in which portion of it falls under the core zone (strict protection zone) inside the Layawan Watershed. This situation is one of the major challenges in protected area management - how to mainstream land use of inhabitants with conservation goals. 


\section{Layawan Watershed Land Cover Map}

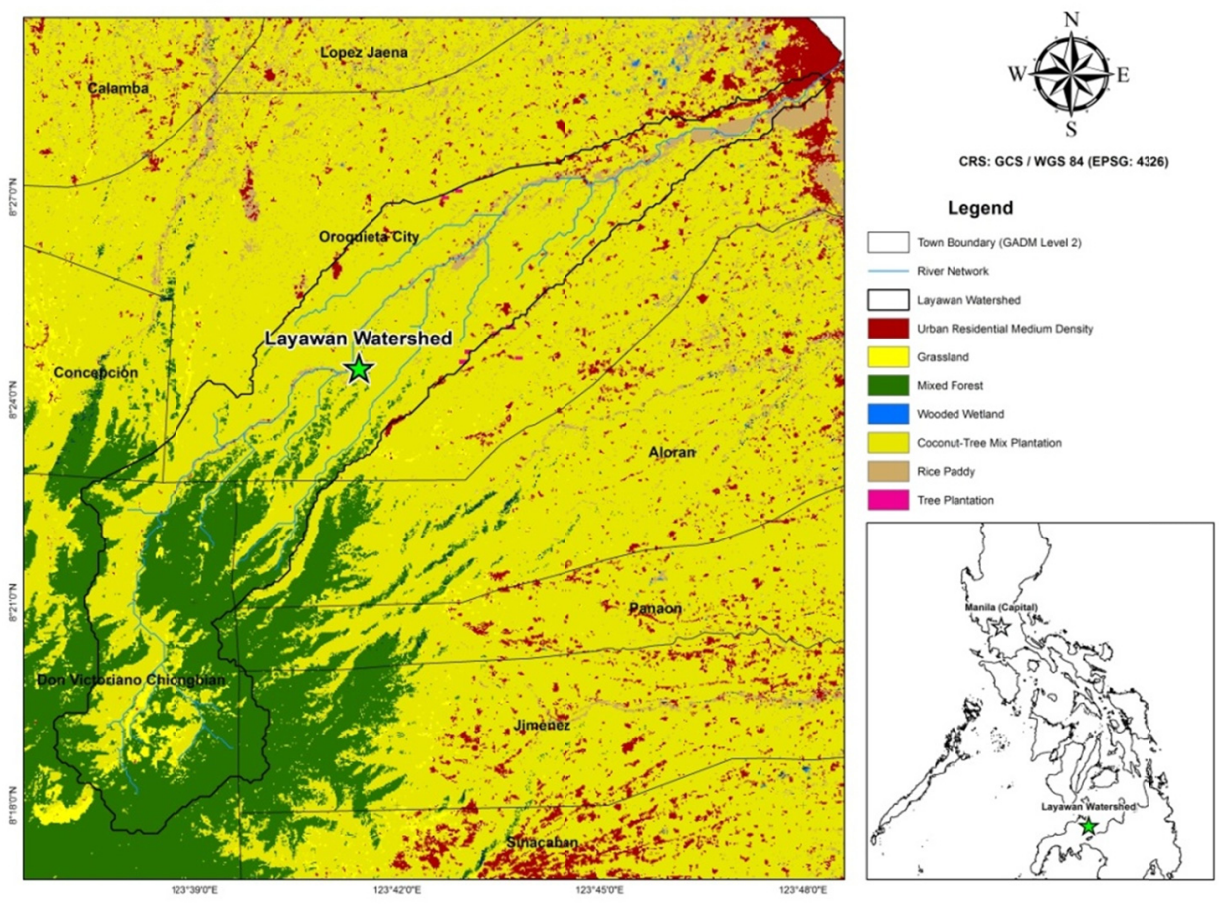

Figure 1. Location of the study site (Layawan Watershed)

The climate classification in the Layawan Watershed, as well the whole Misamis Occidental, is considered to be Type 2 according to the Corona System of classification. It is described as no dry season, with a very pronounced maximum rainfall during the months of November to December (DOST, 2011). This is well observed in the study site, aside from some rainy periods throughout the month of February during the study period which is from July 2011 to November 2012.

The soil types in Layawan are classified into upland and lowland soils. The upland soils are classified as Mountain soil (undifferentiated), Guimbalaon clay loam, Adtuyon clay loam, while the lowland soil is comprised of Quiangua silt loam. Upland soils are characterized as erodible, since most of these soils are located in areas with steep slopes. This erodible nature of the soils can be accelerated if the vegetation is not suitable. Adtuyon clay loam is the most extensive upland soil in the Province of Misamis Occidental, it covers $15.28 \%$ of the total area. The main crops grown on this soil type is coconut. Guimbaloan clay loam covers $13.16 \%$ of the province. Common vegetation found on this type of soil is secondary forest and grasses, while some coconut has been planted in the lower slopes. Mountain soils (undifferentiated) covers $26.86 \%$ of the province, which is composed of thick forest. However, forest area has decreased since the assessment of the Bureau of Soils in the Province. In the lowland, Quiangua silt loam only covers $0.99 \%$ of the province. It occupies the flood plains of Langaran River and the lowland areas of Oroquieta City. This type of soils is mostly devoted to rice paddy agriculture (Bureau of Soils, 1970).

Different policy zones overlap in Layawan Watershed, some of these laws are the Revised Forestry Code of the Philippines (PD 705), Local Government Code of the Philippines (RA 7160), National Integrated Protected Areas System (NIPAS) Act (RA 7586), and The Indigenous Peoples' Rights Act (IPRA) (RA 8371).

\subsection{Hydrologic Modeling}

The Soil and Water Assessment Tool (SWAT) was used for hydrologic modeling to quantify the impacts of existing land use and land use change on sediment concentration and sediment yield in the Layawan Watershed. The SWAT Model is a watershed scale model used to quantify the impact of land management and practices on large complex watersheds. It has been used by many scientist and researchers to predict the impact of land management on soil and water resources (George \& Leon, 2007). Unlike other modeling tools, SWAT utilizes readily available spatial data on the physical characteristics of the watershed. Data that were used to set-up the model are freely accessible via the web. MapWindow GIS ${ }^{\circledR}$ was used as a platform to run the SWAT Model. 
Since the local rainfall data is on a daily time-step, the model was run from June 2011 to September 2012 on a monthly printout frequency.

\subsubsection{Digital Elevation Model}

The SRTM Version 4.1 Geotiff 90-meter resolution (Jarvis et al., 2008) digital elevation model (DEM) was downloaded from http://srtm.csi.cgiar.org/ and was used for terrain analysis, including watershed and river network delineation. However, the DEM cannot accurately delineate the river network in flat topography. In this case, it needs pre-processing before it can be used for modeling. Some channels from nearby watersheds are being drawn to the Layawan River. In this case, another tool and GIS technique was used to correct the DEM.

The delineated river network derived was validated using participatory approach and in Google Earth ${ }^{\circledR}$. A participatory approach was used mainly for resource mapping, and secondarily for river network validation. In the activity, the community identified two inaccurate major tributary that is supposed to be draining to another river adjacent to the Layawan Watershed. Since the DEM cannot accurately identify rivers in the relatively flat terrain in the downstream portion of the watershed, the delineated river network was edited using Google Earth ${ }^{\circledR}$ and used as reference for DEM reconditioning. This process is important if using coarse resolution DEM. Arc Hydro ${ }^{\circledR}$ was used for DEM reconditioning in the downstream portion of Layawan River. The Arc Hydro operates in the ArcGIS environment and is a tool that supports water resources applications (ESRI, 2011). The downstream portion of the river was better represented after the reconditioning.

\subsubsection{Land Cover Data}

A 30-meter resolution satellite image from Landsat 5 thematic mapper downloaded from USGS Glovis website (http://glovis.usgs.gov/) was used to obtained land use data for 2010. It has path and row 113 and 054 (ID LT51130542010038BKT00), respectively. The satellite image was analyzed and processed using IDRISI Selva ${ }^{\circledR}$ maximum likelihood image classification module. The classification was based on the global land use and crop databases of SWAT 2005 and SWAT 2012. The satellite image was classified into forest (FOMI or mixed forest), coconut (COCO or Coconut), rice land (RICE), grassland (GRAS or grassland), built-up area (URMD or Urban Residential Medium Density), mangrove (WEWO or Wooded Wetland), and lake (WATB or Water Body). The training sites used to classify the satellite image were created from GPS survey, participatory resource assessment, and in Google Earth ${ }^{\circledR}$, since it has a high resolution view of the landscape of Mt. Malindang, especially the headwaters of Layawan Watershed. The derived raster land cover was converted to vector type for land use correction, and then converted back again to raster as land cover input to the SWAT Model.

Landsat 5 Thematic Mapper (TM) cannot detect small land uses such as small tree plantations. Coordinates of tree plantations from recently conducted resource survey in the uplands were included in the land cover map. The area of the tree plantations are estimated at around two hectares each.

\subsubsection{Soils Data}

The Digital Soil Map of the World (DSWM) was used for modeling. The DSWM was acquired from the Food and Agriculture Organization (FAO) website (http://www.fao.org/geonetwork/srv/en/metadata.show?id=14116) (FAO, 2003). The FAO soil classification is well supported by the usersoils database of SWAT. The soil vector type was converted to raster carrying the SNUM code in the attribute data. SNUM is a sequential code, unique for each Soil Mapping Unit, which links the first level of soil information to the expansion data file (FAO, 2003). The soils of the Layawan Watershed belongs to the following classification of FAO: Bg8-2-3a-4478 (SNUM: 4478); Ne65-3bc-4546 (SNUM: 4546); and To27-2-3b-4578 (SNUM: 4578).

\subsubsection{Climate Data}

Climate data such as rainfall, temperature, wind speed, humidity, and solar radiation are the meteorological data inputs in SWAT. The climate data was acquired from the Philippine Real-Time Environment Data Acquisition and Interpretation for Climate-Related Tragedy Prevention and Mitigation (PREDICT) website (http://fmon.asti.dost.gov.ph/weather/predict/) (DOST, 2013). The PREDICT project is a nationwide system that complements the existing climate observation of the Philippine Atmospheric Geophysical Astronomic Service Administration (PAGASA). It consists of a network of automatic weather stations (AWS) that transmit observation data to the central server. The AWS feeds real-time observed climate data to the server every 15 minutes which is posted to their website. The AWS in Layawan was installed and became functional last June 2011. Hence, the meteorological data that was gathered to run the model started June 2011.

The SWAT Model can simulate missing weather data values, which corresponds to a -99 value in the dataset. Missing values are needed especially in weather datasets of one year of less. In the weather dataset, missing weather data values were added to extend the model set-up dates to include a one-year warm-up period and to 
facilitate the creation of the climate database. The warm-up period or the number of years skip (NYSKIP) is essential for better prediction of results. Without the warm-up period, the model tends to overestimate the result during the initial model simulation. On the other hand, SWAT Weather Generator Program was used to generate climate data for the Layawan Watershed.

\subsubsection{Model Parameterization}

Model parameterization is an important consideration in modeling. The parameters such as crop factor (C) and soil erodibility $(\mathrm{K})$ coefficients were modified to suit the local conditions in the Layawan Watershed. Modification of land cover and soil erodibility coefficients are important since the values will vary with local conditions. The values of $\mathrm{C}$ and $\mathrm{K}$ coefficients in the SWAT database are somewhat general and should be carefully used. They were modified to better represent the cover and soil conditions in the watershed. The $\mathrm{C}$ and $\mathrm{K}$ coefficients that were used are those suggested by David (1988). For instance, the coconut land use $\mathrm{C}$ value was changed to 0.05 that represents a coconut with tree intercrops, and grassland $\mathrm{C}$ value was changed to 0.2 to represent grassland which is moderately grazed, and occasionally burned. These land use conditions was observed in the Layawan Watershed.

Support practice factor (USLE_P) for coconut land use were also modified to reflect the management practice of coconut in the project site. The default value of MWSWAT for USLE_P is 1.0 which represents conventional tillage or no surface cover (David, 1988). The USLE_P coefficients that were used are those suggested by David (1988) which represents the typical land management practice in Layawan Watershed. For coconut plantation land use, the value was modified to 0.23 which represents trees covering $75 \%$ of the plot, and $60 \%$ vegetation at ground surface. The runoff curve number (CN2) for coconut plantation was also modified from 77 to 72 . The modified value represents a hydrologic soils group of $\mathrm{C}$ with a vegetation cover of woods-grass combination (orchard or tree farm) with good hydrologic condition (Neitsch et al., 2005). The various runoff curve number values can be found in the 2:1.1.1 under Chapter 2.1: Equations-Surface Runoff in the Soil and Water Assessment Tool Theoretical Documentation Version 2005 (Neitsch et al., 2005).

\subsubsection{Land Use Scenario Modeling}

\section{Scenario 1 - result of the Community-Based Watershed Management Planning}

The first scenario utilized the result of the Community-based Watershed Management Planning Workshop conducted in the upland, midland, and lowland portions of the Layawan Watershed (Anit et al., 2012). This scenario involves riverbank stabilization, utilization of agroforestry system to optimize the use of grassland areas, forest conservation, and without expansion of coconut plantation. For riverbank stabilization, shrubs will be planted 15 meters on both sides of the riverbank. According to the report of the German Agency for Technical Cooperation, LTD. (1975), planting shrubs are the preferred method of riverbanks stabilization in the low to medium water level zones. In our spatial data, the main river and major tributaries were buffered by 30 meters and is assigned as shrub land use (SHRB). The 30-meter buffer is to make sure that at least one pixel will be selected since the resolution of the satellite image is 30 -meters. On the other hand, grasslands were converted to agroforestry.

The agroforestry zone consists of rubber-corn-row crops (RCRC) mix in the headwaters, and rubber-cacao (RUCO) cropping mix in the midland and lowland. In the headwaters, the proportion of each land use is as follows: $20 \%$ row crops, $30 \%$ rubber, and $50 \%$ corn. The premise behind these proportions is the community's complaints that strong winds affect the crop yield of corn negatively. Hence, rubber trees will serve as windbreaks which will cover at least $30 \%$ of the planted area. Row crops will provide staple food for the community while waiting for the corn harvest, hence it will cover at least $20 \%$. Corn as the major crop will cover the majority of the planted area $(50 \%)$. On the other hand, the rubber-cacao mix agroforestry system was preferred by the midland and lowland communities. The crop coefficient (USLE_C) of the two agroforestry systems was estimated using the combination of the different USLE_C values and the percent coverage of each land use. The USLE_C coefficient or C value for RCRC mix was estimated at 0.1403 and RUCO mix was 0.001 . The following formula was used to compute the relative changes in C-factor for RCRC, and same method was used for RUCO:

$$
\mathbf{A F}_{-R C R C_{\text {USLE_C }}}=\left(\mathbf{R}_{\mathrm{C}}+\mathbf{R}_{\%}\right)+\left(\mathbf{C}_{\mathrm{C}}+\mathbf{C}_{\%}\right)+\left(\mathbf{R C}_{\mathrm{C}}+\mathbf{R C}_{\%}\right)
$$

\section{Scenario 2 - degradation scenario}

The second scenario involves the degradation of forest in the critical sub-basins (sub-basins with high sediment yield). It is assumed that there is no conservation initiative implemented in the critical sub-basins, and that there are no funds to fully implement the watershed management or protected area programs and projects. Considering 
the economic status of the upland community, especially the indigenous people, it leads to indiscriminate conversion of forest from critical sub-basins into grasslands. The USLE_C value of grassland in the SWAT database was modified to 0.4 which represents grassland that is overgrazed and regularly burned.

\subsection{Model Limitation}

The SWAT Model results were not calibrated because of the lack of continuous data on observed stream flow, sediment concentration and sediment yield data. The Layawan Watershed is a typical example of an un-gauged basin. The only record of streamflow in Layawan Watershed was published by the National Water Resources Council in 1980. The National Irrigation Administration in Oroquieta established their streamflow gauging station along the Layawan River but it was decommissioned more than a decade ago. After that, very few studies have been conducted to quantify stream flow and total suspended solids in the watershed. River discharge and sediment concentration is affected by land use and climate. Since, there is no established rain gauge station in the Layawan Watershed and land use has changed over time, the historical data cannot be used for calibration.

\section{Results}

\subsection{Sediment Concentration and Sediment Yield Under Baseline Condition}

Sediment concentration $(\mathrm{mg} / \mathrm{kg}$ ) and sediment yield (tons/ha) were modeled on a monthly time-step. The result of the simulation shows that Sub-basin 6 has the highest sediment concentration with $14452.63 \mathrm{mg} / \mathrm{kg}$, while Sub-basin 1 has the lowest sediment concentration with $2458 \mathrm{mg} / \mathrm{kg}$ (Figure 2). Sub-basin 6 is one of the major tributaries, located in the middle portion of the Layawan watershed, with $85 \%$ of its slope belonging to $>18 \%$ and $70 \%$ of the area is devoted to coconut plantation. While the land use of Sub-basin 1 is purely agricultural, the slope classification of Sub-basin 1 is mostly flat to rolling terrain which explains the low sediment concentration.

Simulation results also show that sub-basin 13 and 15 have high sediment yield, at 120 and 117 tons/ha respectively. Sub-basin 13 is dominated by $>50 \%$ slopes with $94 \%$ of its land use is classified as coconut plantation. On the other hand, $87 \%$ of the slope in Sub-basin 15 is classified as $>18 \%$ and $90 \%$ of its land use were considered as coconut plantation. The elongated shape of the watershed indicates that it has extensive steep slopes, and this characteristic should be carefully considered in planning and in any interventions.

Soil in the middle portion of the Watershed is considered to be erodible (Bureau of Soils, 1970) while the upland soil types of the Layawan Watershed are classified as steep, and very severely to excessively eroded. According to the report of the Bureau of Soils (1970), these types of lands are unfit for extensive cultivation and proper land management should be practiced. These factors explain the high sediment concentration and sediment yield in the middle portion of the watershed.
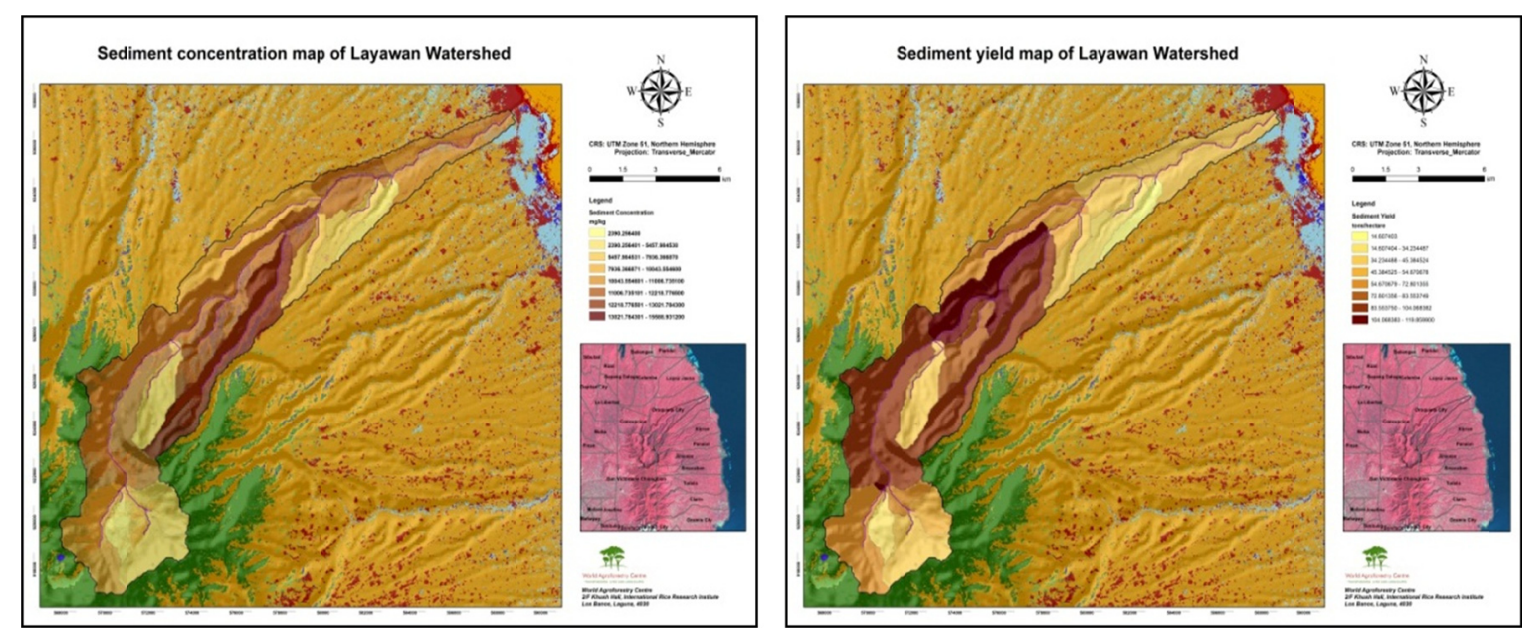

Figure 2. Sediment yield of Layawan Watershed under baseline scenario

Note: The figure shows high sediment yield in the middle portion of the watershed.

Based on the SWAT simulation for sediment yield under the baseline scenario, six critical sub-basins located in the middle portion of the watershed were identified. These are sub-basins 4, 5, 6, 14, 15, and 16 (Figure 2). Most 
of the critical sub-basins are within the Mt. Malindang Range Natural Park (MMRNP), meaning it has high potential for interventions aimed at land use improvement. The land use of the sub-basins are devoted to coconut plantations which comprised more than half of the land area and majority of the slope are classified as steep to very steep. These are the areas that should be targeted and considered priority areas for conservation and interventions, such as payment for ecosystem services (PES). The PES scheme involves the change or maintenance of land use to improve or maintain certain ecosystem services.
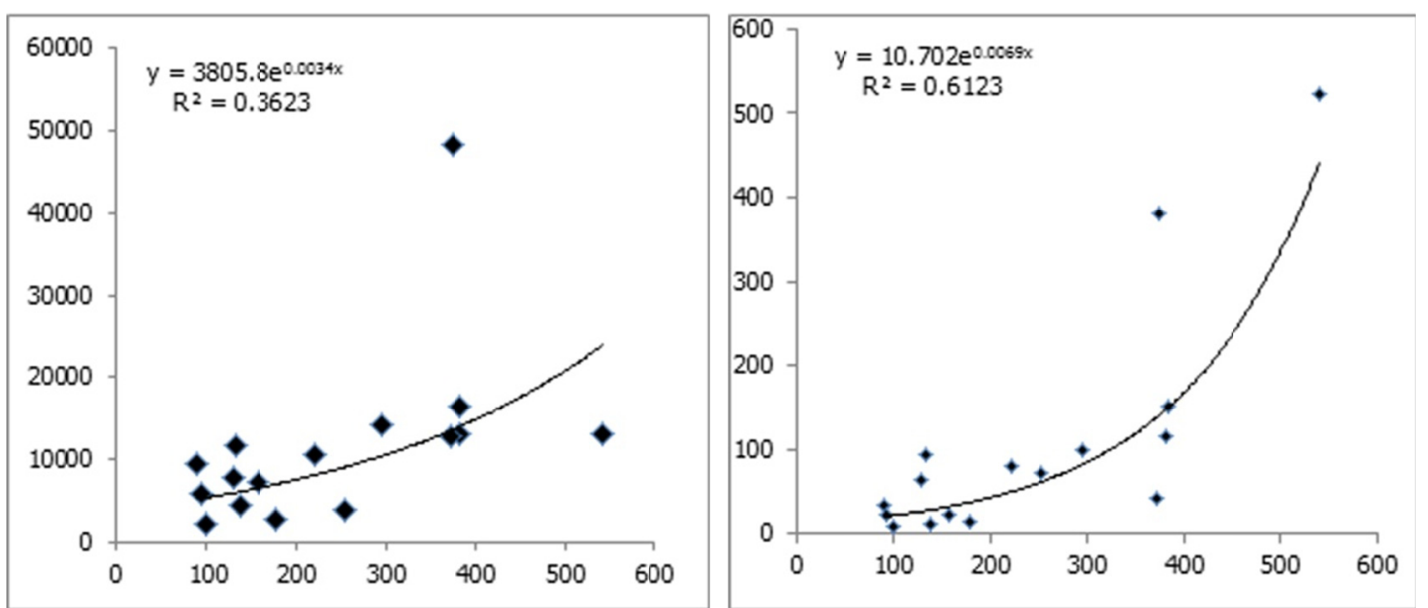

Figure 3. Correlation of simulated sediment concentration (a) and sediment yield (b) to rainfall. Values are averages of critical sub-basins

This study focused on two key variables that are important in watershed management: sediment concentration and sediment yield. These two variables are caused by soil erosion, and are associated with the current land use, land management practices, as well as policies.

Figure 3 shows the correlation of sediment concentration and sediment yield to precipitation. The result shows that sediment yield is more sensitive to precipitation with an $r$ value of 0.782 . An area sensitive to sediment yield means that the vegetation cannot hold the soils effectively, and cannot withstand the erosive nature of precipitation and runoff. The relatively lower sensitivity of sediment concentration to precipitation can be explained by the nature of adjacent land use, topography, and frequency of precipitation, and the ability of the riparian vegetation to hold back the soil.

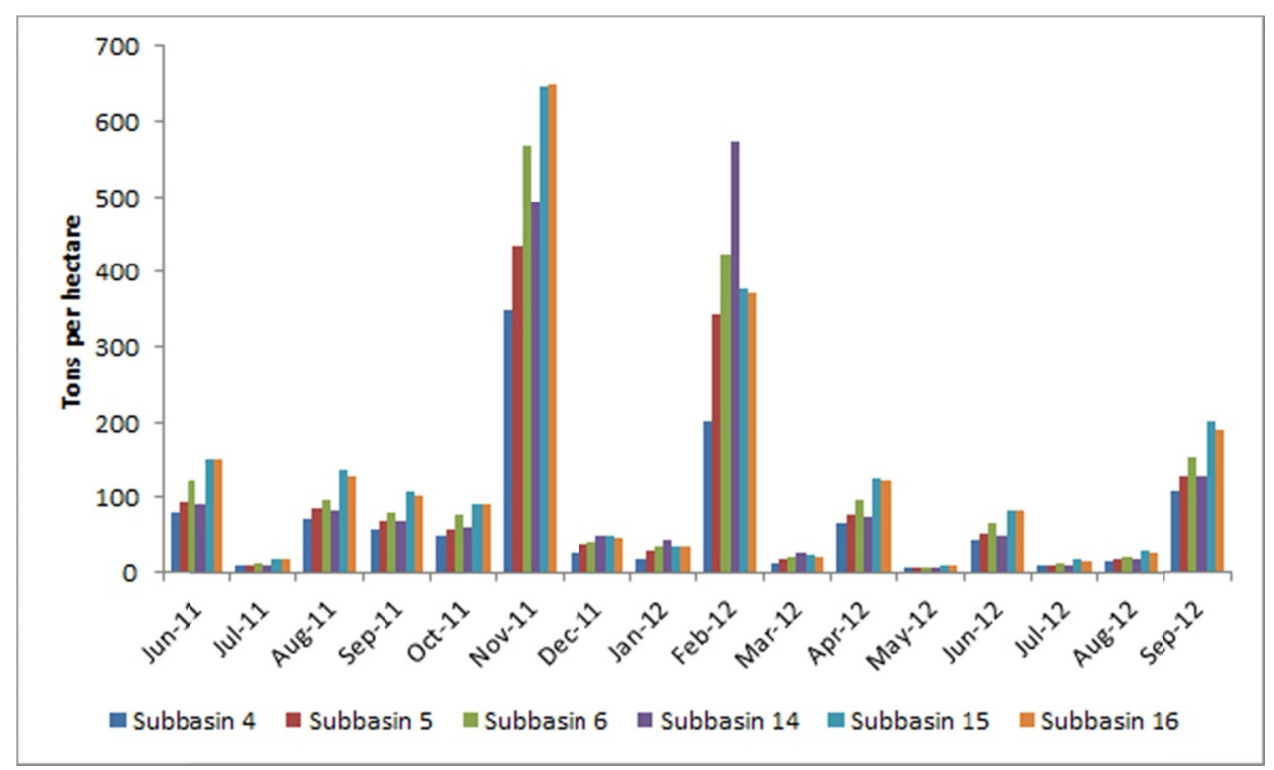

Figure 4. Sediment yield under baseline scenario 
Figure 4 shows the sensitivity of sediment yield to precipitation. This scenario can also be observed in other sub-basins. The abrupt increase in sediment yield during months with high precipitation means that the current land use is prone to erosion. This should not be the case if the vegetation can effectively hold the soil during runoff events.

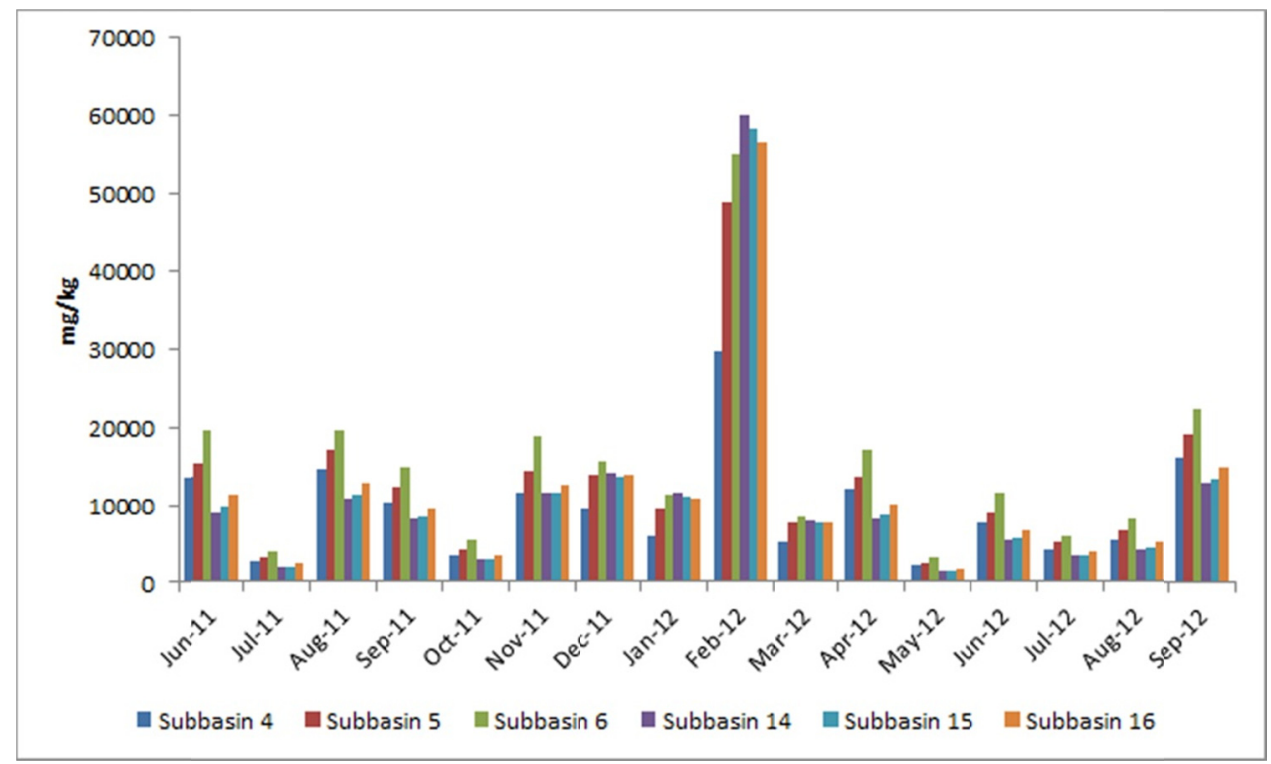

Figure 5. Simulated sediment concentration in Layawan Watershed

Figure 5 shows the response of sediment concentration to precipitation. It shows that sediment concentration did not increase rapidly during the first heavy rain event in November and December 2011. However, during the second heavy rain event on February 2012, sediment concentration dramatically increased. This can be explained by the adjacent vegetation to the river network and the sources of erosion. The type of vegetation, distance of sources of erosion, and topography determines the lag time before the soil can find its way to the streams. It can be inferred that during the first heavy rains, some of the soils were eroded but did not find its way to the river, but rather deposited to other areas and became immobile. These deposited soils must have been transported to the streams during the second onset of heavy rain. This implies the importance of riparian and good vegetation cover near or adjacent the river system to trap soil.

During the participatory resource assessment conducted in the upland and midland portion of the watershed, some of these critical sub-basins have been identified by the communities as threat to the water resources due to erosion. Moreover, these sub-basins have also been identified by the Department of Environment and Natural Resources (DENR) as areas with high erosion (DENR, 2003). Based on direct observation by one of the project consultants, the upper portion of the watershed has clearer water which indicates low susceptibility to erosion. This observation is consistent with the result of the simulation, where the middle portion of the watershed has turbid water indicating high sediments in the streams. 


\subsection{Sediment Yield and Sediment Concentration Under Scenario 1}

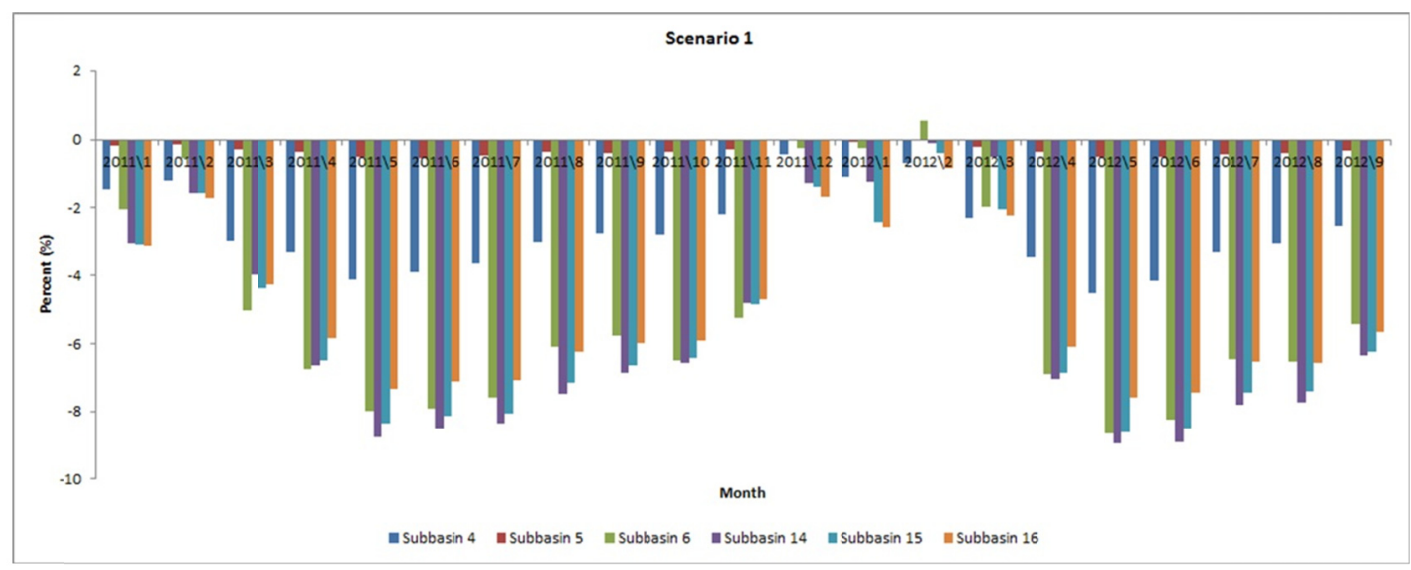

a

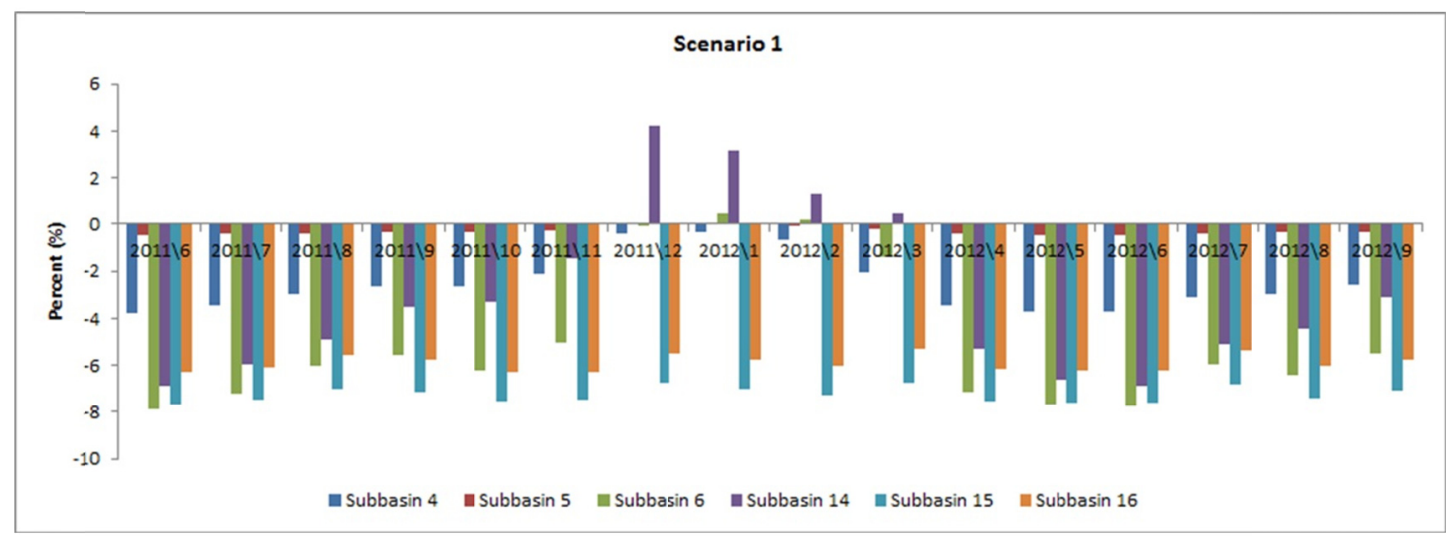

b

Figure 6. Percent changes in sediment concentration (a) and sediment yield (b) from baseline scenario under scenario 1

Figure 6 shows the changes in sediment concentration in the Layawan Watershed if the Community-based Watershed Management Plan will be implemented. The plan involves riverbank stabilization along major river tributaries and conversion of grasslands to agroforestry systems. If the plan will be implemented by the community and major stakeholders of the watershed, there will be an average of $0.32 \%(32 \mathrm{mg} / \mathrm{kg})$ to $5.55 \%$ $(581 \mathrm{mg} / \mathrm{kg})$ monthly reduction in sediment concentration in the identified critical sub-basins.

Additionally, scenario 1 will lead to an average of $0.2 \%(0.21$ tons/ha) to $7 \%(9.63$ tons/ha) reduction in sediment yield in the critical sub-basins. The decrease can be primarily attributed to the improved land cover, especially the conversion of grasslands to agroforestry system. Instead of burning the grasslands to provide temporary food, the conversion to agroforestry system allows for a permanent soil cover that will reduce soil erosion.

Practicing agroforestry provides for more benefits, including the following: increased income opportunities: a year round distribution of employment and income; variety of products and/or services; various crops can be produced for the same piece of land: some of these are food, firewood, posts, poles, craft wood, fodder, fertilizer, and medicinal products; potential for improved human nutrition; can provide a wide range of edible plants for human consumption; and crop diversity and reduced risks: helps attenuate price fluctuations of a single crop and help reduce risk of total crop loss in case of pest attack (MacDicken \& Vergara, 1990). 


\subsection{Sediment Concentration and Sediment Yield under Scenario 2}
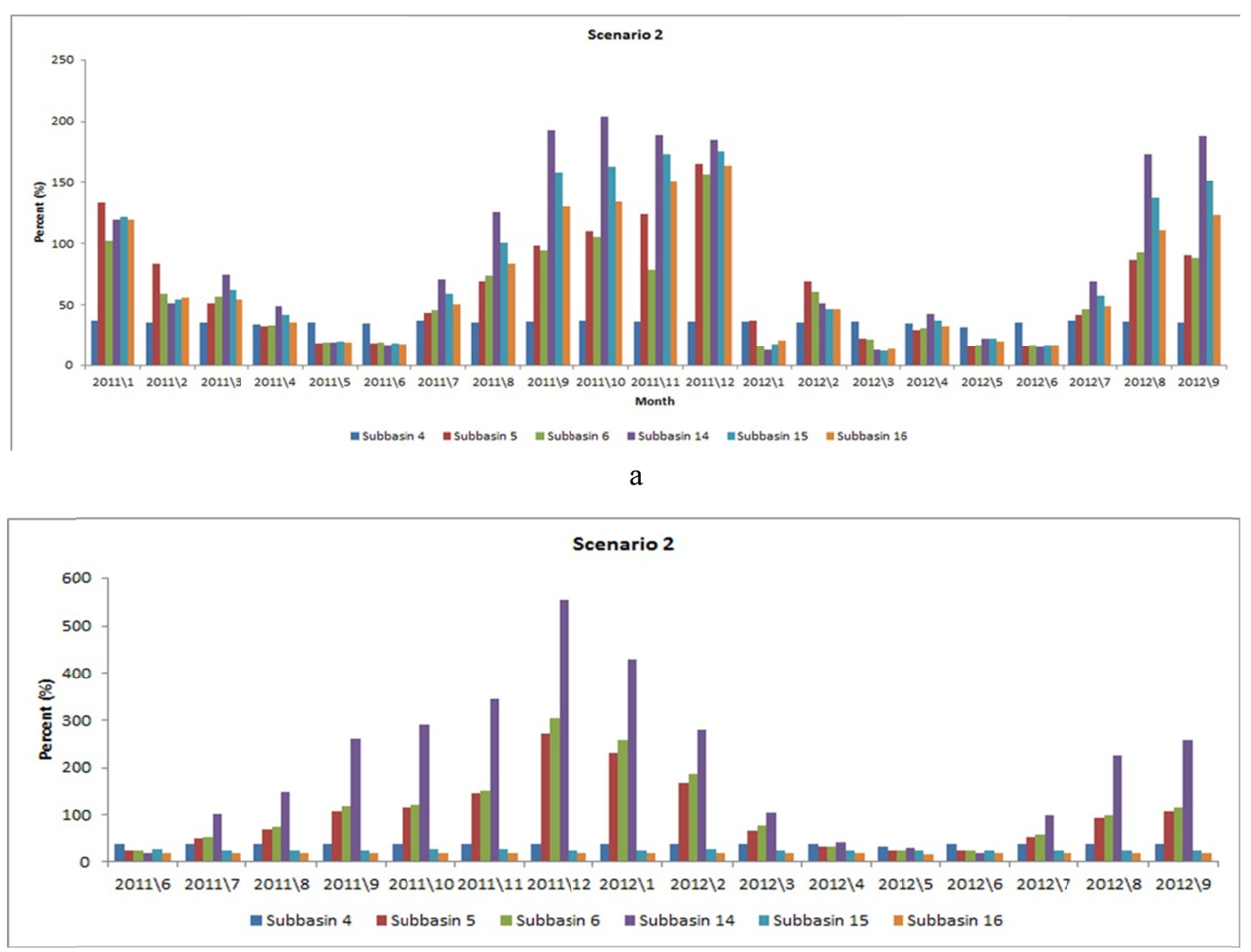

b

Figure 7. Percent changes in sediment concentration (a) and sediment yield (b) from baseline under scenario 2

Scenario 2 (degradation scenario) involves the conversion of forest to degraded grasslands. In this scenario, grassland is regularly burned and overgrazed. This scenario is assumed to happen if policies, programs, and projects on forest conservation and land management (i.e., regulating agricultural expansion and practice) are not properly implemented; illegal activities become rampant in the critical sub-basins, and no conservation initiatives are implemented to improve the land use of the local communities. This scenario will lead to a dramatic increase in sediment concentration and sediment yield in the critical sub-basins. There will be a $35.63 \%$ (3 $483 \mathrm{mg} / \mathrm{kg}$ ) to $89.74 \%(9,675 \mathrm{mg} / \mathrm{kg}$ ) increase in sediment concentration in each river system of critical sub-basins (Figure 7).

At the same time, under scenario 2, critical sub-basins will experience an increase from $17.6 \%$ to $200 \%$, which translates to 22.76 tons/ha to 294.19 tons/ha increase in sediment yield.

It is also important to consider the downstream impacts of these land use scenarios. River discharge will not be highly affected by the two scenarios. On the average, there will be a decrease of 0.006 cubic meters per second under scenario 1, and an increase of 0.017 cubic meters per second under scenario 2. On the other hand, sediment concentration will decrease by an average of $4 \%(285 \mathrm{mg} / \mathrm{kg})$ under scenario 1 . However, sediment concentration will increase several folds $(8024 \mathrm{mg} / \mathrm{kg}$ ) under scenario 2 . This indicates that although river discharge will not be heavily affected, the change in land use in the upstream areas will surely alter the water quality downstream. Consequently, this will also affect the sustainability of coastal ecosystems.

\section{Discussion}

To investigate changes in land use and its effect on sediment yield and concentration, two land use scenarios were developed and simulated. The first scenario is the improvement of existing land use in the watershed. The grassland in the upper portion and middle portion of the watershed was converted to agroforestry system, the 
river bank along the main river and major tributary were planted with shrubs, forests were conserved, and existing coconut plantations were maintained. If these land uses are implemented in the watershed, it will lead to an average of $4 \%$ reduction in erosion and sedimentation in the streams. This initiative is feasible since it is based on the community-based watershed management plan developed as part of the project initiatives. Scenario 1 is based on the desired and doable actions of the local community in the upstream, mid-portion, and downstream portion of the Layawan Watershed.

However, under scenario 2 or if forests are converted to grasslands, the consequence will yield an average increase of $106 \%$ in soil erosion and sedimentation. The cost will be very high if forest areas will be degraded. Scenario 2 will not heavily affect the quantity of water, however it will highly affect water quality through increased water turbidity and pollution. This will have an impact on the productivity of the aquatic habitat. Various freshwater species in the Layawan River, like freshwater shrimp and small fishes, are gathered for domestic consumption. Increased sedimentation will also affect the coastal area, especially in the primary impact zone - the Plume - of the watershed through increased transport of soils which carry various types of pollutants. It is important to note that a substantial part of the watershed is covered by the protected area. Hence; stakeholders such as the local government unit, NGOs, academic institutions, and line agencies; should work coherently, consistently, and concertedly to avoid further degradation of the critical sub-basins. The PAMB only have jurisdiction over the upstream portion of the watershed. Although upstream areas are considered vital in management, this only covers half of the watershed. Other activities in the lowland areas also affect the quality and quantity of water. An integrated watershed management should be considered in Layawan Watershed.

It is shown in the model results that there is a high stake if forest will be degraded in the critical sub-basins. Large portions of the identified sub-basins are located inside the MMRNP: 20\% in the buffer zone and 52\% in the core zone. According to the draft management plan for MMRNP, many activities are programmed for the conservation of watersheds. Some of the notable activities include the establishment of a community-based watershed management council, reforestation, eco-tourism, assistance for improved farming system (agro-forest farm), and development of land use plans in the buffer zones (PAMB, ND). So far, many of these targets have not materialized due mainly to lack of funds to implement the activities. One approach to address the issue of limited budget allocation in managing watersheds is through payments for ecosystem services. The PES system generates its own funds, which are meant for use in the conservation of the watershed through improved land use of the local communities in the upstream areas. It is hoped that less forest will be cleared if land use will be improved (Tappan \& McGahuey, 2007). In the Layawan Watershed where communities in the upstream portion are present, uncontrolled human activities can lead to irreversible damage to water and ecosystems in the downstream areas.

\subsection{Implications to PES}

The scenarios presented are particularly important in implementing conservation initiatives such as a payment for ecosystem services (PES) scheme. The PES scheme involves either maintenance or changes of current land use, where maintenance follows the precautionary principle. The preservation of land use is aimed at preventing dramatic changes in the hydrologic regime that could drastically affect important ecosystem services. On the other hand, the improvement (change) of the current land use is directed to reverse the degradation of important ecosystem services. Some of the questions surrounding the success of payments for ecosystem services are the following: (1) if a certain intervention will be financed by buyers, will they benefit from such transaction; (2) how will ecosystem services change if the land use is not properly regulated; and (3) where are the pilot sites that will be targeted for PES. These key questions need to be carefully considered, undertaken, and presented to the stakeholders so that there will be a concrete basis for transacting ecosystem services, hence a greater chance that PES will be successful.

In this study, two land use scenarios were modeled using the SWAT Model to quantify changes on key factors affecting ecosystem services - sediment yield and sediment concentration - in the Layawan Watershed. The result of this modeling, which is indicated in the earlier portion of this paper, will serve as basis for transacting with the buyers the likely impact of improved or degraded landscape in the upstream portion of the watershed.

The use of the SWAT model to identify the critical sub-basins in the Layawan Watershed is vital in PES. These sub-basins are potential target sites for PES in the Layawan Watershed to ensure that intervention will have an impact on water quality. Moreover, the SWAT model was able to quantify the changes in sediment yield and sediment concentration in the stream that is also essential to the implementation of PES since the efficiency of a PES mechanism depends on the additionality derived from it. An economic valuation of changes in sediment yield in terms of nutrient transport can also serve as another medium for PES, which is also simulated by SWAT. 
Interventions to improve the current land use that will reduce soil loss will definitely lead to tangible improvements in the water quality where the downstream and coastal communities will benefit.

Modeling is an essential tool for PES implementation. One key characteristic of a PES scheme is conditionality, wherein beneficiaries pay only if the service is actually delivered (Wunder, 2005). One problem is it would take a number of years before the results of the conservation activities are observed. The SWAT Model can quantify long term impacts of land management practices on factors affecting key ecosystem services, depending on what service is transacted. Moreover, the SWAT model can simulate the impact of specific land uses, such as agroforestry - combination of rubber, corn, and row crops or rubber agroforestry - on key ecosystem services.

\section{Conclusion}

The SWAT Model has identified the critical sub-basins in the Layawan Watershed which is important for many environmental managers and development workers to guide future development plans and conservation initiatives. Moreover, SWAT has simulated the likely changes in sediment yield and concentration for the two land use scenario - improvement and degradation scenario. The impact of these scenarios cannot be easily assessed without the aid of models. With this modeling tool, government agencies and other private organizations may now precisely target critical locations in the watershed, and have a more certain (quantifiable) impact assessment of activities, especially the programs and projects in the watershed before it can implemented. It is shown that the transfer of sediments will drastically increase if there are no safety nets to regulate the conversion of agricultural lands to degraded grasslands. The increase in sediments has a definite impact on the river and coastal ecosystem. This has potential negative impact on fisheries both in the river and coastal area, as well as the utilization of river water.

With the increasing popularity and practice of PES as a viable conservation tool, more development agencies and government institutions are delving into such conservation initiative. However, the implementation of PES is plagued with issues such as targeting of location, quantification of ecosystem services, and the quantification of benefit that will be derived by the buyers. If these issues are not addressed, they will affect the success of PES. Use of models is imperative for the success of PES as well as managing the watersheds. It was shown in this study that, SWAT Model has been able to quantify the relative changes in sediment loads in streams using two land use scenarios. In this case, PES facilitators and implementers can have concrete evidence - not just pure assumptions - for negotiating payments to the stakeholders.

Spatial and temporal models like SWAT could be used by local stakeholders, especially local government agencies and line agencies, in examining and quantifying the impacts of various programs and projects on soil and water resources. Some programs are developed and implemented with little knowledge on how it will affect the soil and water resources. Most often, the assessments of impacts are made from pure assumptions with little scientific basis and no quantifiable measurements of impacts. This situation arises because many environmental agencies (either government or non-government organizations) in developing countries do not have the capacity to use sophisticated Geographic Information System (GIS)-based models that can be used for watershed management and planning. Lack of resources and expertise (knowledge on GIS and modeling discipline) impedes the use of GIS-based models that would otherwise be a vital component in planning and decision making. Expertise can be built through capacity building, however, financial resources often cannot be remedied. The advent of open source GIS and mainstreaming of sophisticated models provide a viable tool for budget constraints agencies (non-government and grass-roots organizations) to conduct assessments that are vital for formulating development plans and reverse watershed degradation; identifying and quantifying the potential impacts of planned development initiatives (programs and projects) and proposed project implementation, and assess the current condition of the watershed. The integration of models to open source GIS could revolutionize watershed management, especially in developing countries. Another advantage of using open source GIS-based models is that it can be cascaded and disseminated to local agencies, academic institutions, and even reach the smallest possible administrative unit (barangay) that has a stake in watershed management to facilitate relevant decisions and well-implemented programs and projects.

\section{Acknowledgements}

This research was made possible through the support of United States Agency for International Development (USAID) and the World Fish Centre. However, the author's views expressed in this report do not necessarily reflect the views of the USAID or the United States Government. Likewise, a warm thanks to the Local Government of Oroquieta City for providing assistance during field works. 


\section{References}

Alibuyog, N. R., Ella, V. B., Reyes, M. R., Srinivasan, R., Heatwole, C., \& Dillaha, T. (2009). Predicting the effects of land use change on runoff and sediment yield in Manupali River Subwatersheds using the SWAT Model. International Agricultural Engineering, 18(1-2), 15-25.

Anit, K. A., Salvador, M., \& Llanza, M. (2012). Community-based Watershed Management Plan.

Arnold, J. G., Kiniry, J. R., Srinivasan, R., Williams, J. R., \& Neitsch, S. L. (2011). Soil and water assessment tool: Input/output file documentation version 2009. Texas Water Resources Institute Technical Report No. 365. Texas A\&M University System College Station, Texas 77843-2118.

Brooks, K. N., Ffolliott, P. F., Gregersen, H. M., \& DeBano, L. F. (2003). Hydrology and the management of watersheds (3rd Ed.). Iowa State Press, A Blackwell Publishing Company. ISBN 0-8138-2985-2.

Burden, F. R., McKelvie, I., Förstner, U., \& Guenther, A. (2002). Environmental monitoring handbook. McGraw-Hill Companies, Inc.

Bureau of Soils, ND. Land Resources Evaluation Project. Physical Land Resources of Misamis Occidental. Volume 1.

Bureau of Soils. (1970). Soil survey of Misamis Occidental Province, Philippines.

David, W. (1988). Soil and water conservation planning: policy issues and recommendations. Journal of Philippine Development, XV(26), 47-84.

DENR (Department of Environment and Natural Resources). (2003). Profile of Layawan River Watershed.

DOST. (2011). Climate Projections. Retrieved from http://kidlat.pagasa.dost.gov.ph/cab/climate_change/ClimateProjections.html

DOST. (2013). Philippine Real-Time Environment Data Acquisition and Interpretation for Climate-Related Tragedy Prevention and Mitigation. Retrieved from http://fmon.asti.dost.gov.ph/weather/predict/

ESRI. (2011). Arc Hydro Tools Overview Version 2.0.

FAO (Food and Agriculture Organization). (2003). The Digital Soil Map of the World Version 3.6. Retrieved from http://www.fao.org/geonetwork/srv/en/metadata.show?id=14116

Ficklin, D. L., Luo, Y., Luedeling, E., \& Zhang, M. (2009). Climate change sensitivity assessment of a highly agricultural watershed using SWAT. Journal of Hydrology, 374(2009), 16-29. http://dx.doi.org/10.1016/j.jhydrol.2009.05.016

GADM. (2011). Global administrative areas. Retrieved June 8, 2011, from http://www.gadm.org/ on

Gassman, P. W., Reyes, M. R., Green, C. H., \& Arnold, J. G. (2007). The Soil and Water Assessment Tool: Historical development, applications, and future research direction. American Society of Agricultural and Biological Engineers, 50(4), 1211-1250. ISSN 0001-2351.

George, C., \& Leon, L. F. (2007). WaterBase: SWAT in an open source GIS. The Open Hydrology Journal, 1, 19-24. Bentham Science Publisher Ltd. 1874-3781/07 2007.

German Agency for Technical Cooperation, LTD. (GTZ). (1975). Manual of reforestation and erosion control for the Philippines.

Jarvis A., Reuter, H. I., Nelson, A., \& Guevara, E. (2008). Hole-filled seamless SRTM data V4. International Centre for Tropical Agriculture (CIAT). Retrieved from http://srtm.csi.cgiar.org

Lasco, R. D., Villamor, G. B., Pulhin, F. B., Catacutan, D. C., \& Bertomeu, M. (2008). From principles to numbers: Approaches in implementing payments for environmental services (PES) in the Philippines. Smallholder Tree Growing for Rural Development and Environmental Services. Part IV. pp. 379-391. ISBN 978-1-4020-8260-3. http://dx.doi.org/10.1007/978-1-4020-8261-0_17-8261-0_17-Netherlands

Lirong, S., \& Jianyun, Z. (2012). Hydrologic response to climate change in Beijiang River Basin based on the SWAT Model. Procedia Engineering, 28, 241-245. doi:10.1016/j.proeng.2012.01.713

MacDicken, K. G., \& Vergara, N. T. (1990). Agroforestry: Classification and Management. ISBN 0-471-83781-4.

Moradkhani, H., Baird, R. G., \& Wherry, S. A. (2010). Assessment of climate change impact on floodplain and hydrologic ecotones. Journal of Hydrology, 395, 264-278. http://dx.doi.org/10.1016/j.jhydrol.2010.10.038 
Neitsch, S. L., Arnold, J. G., Kiniry, J. R., \& Williams, J. R. (2005). Soil and water assessment tool theoretical documentation. Version 2005.

Palao, L. M., Dressler, W. H., Cruz, R. O., \& Pulhin, J. M. (2011). Changes in indigenous land use system: From swidden to sedentary agriculture. Asia life sciences, 20(2), 395-416. Retrieved from http://journals.uplb.edu.ph/index.php/ALS/article/view/513

PAMB (Protected Are Management Board), ND (No Date). Draft General Management Plan of the Mount Malindang Range Natural Park.

Tappan, G., \& McGahuey, M. (2007). Tracking environmental dynamics and agricultural intensification in Southern Mali. Agricultural Systems, 94, 38-51. http://dx.doi.org/10.1016/j.agsy.2005.07.011

Ullrich, A., \& Volk, M. (2009). Application of the Soil and Water Assessment Tool (SWAT) to predict the impactof alternative management practices on water quality and quantity. Agricultural Water Management, 96, 1207-1217. http://dx.doi.org/10.1016/j.agwat.2009.03.010

USGS. (2011). Global visualization viewer. Retrieved August 15, 2011, from http://glovis.usgs.gov/ on

vanGriensven, A., Ndomba, P., Yalew, S., \& Kilonzo, F. (2012). Critical review of SWAT applications in the Upper Nile Basin countries. Hydrology and Earth System Sciences, 16, 3371-3381. http://dx.doi.org/10.5194/hess-16-3371-2012

Wunder, S. (2005). Payments for environmental services: some nuts and bolts. Occasional Paper no. 42, CIFOR, Indonesia.

Zhi, L., Wen-zhao, L., Xun-chang, Z., \& Fen-li, Z. (2009). Impact of land use change and climate variability on hydrology in an agricultural catchment on the Loess Plateau of China. Journal of Hydrology, 377, 35-42. http://dx.doi.org/10.1016/j.jhydrol.2009.08.007

\section{Copyrights}

Copyright for this article is retained by the author(s), with first publication rights granted to the journal.

This is an open-access article distributed under the terms and conditions of the Creative Commons Attribution license (http://creativecommons.org/licenses/by/3.0/). 